\title{
Groundwater seepage in the marine environment: role for mass flux and bacterial activity
}

\author{
I. Bussmann ${ }^{1, *}$, P. R. Dando ${ }^{2, * *}$, S. J. Niven ${ }^{2}$, E. Suess ${ }^{1}$ \\ 'GEOMAR, Wischhofstr. 1-3, D-24148 Kiel, Germany \\ ${ }^{2}$ Marine Biological Association of the UK, Citadel Hill, Plymouth PL1 2PB, United Kingdom
}

\begin{abstract}
In Eckernförde Bay (western Baltic Sea) pockmark structures are induced by groundwater seeping out of the sediment. On 3 occasions in winter and spring 1993-94 we investigated the influence of groundwater on the reduction of salinity, on porewater chemistry, and on bacterial activities (methane oxidation and sulphate reduction). In 2 out of 3 sampling campaigns ground water discharge could be detected. The concentration gradients of $\mathrm{Cl}^{-}$and $\mathrm{SO}_{4}{ }^{=}$are moved towards the sediment surface by the vertical advection of groundwater during seep times. Without groundwater discharge the porewater chemistry resembled the contral site. Compared to the control site, the methane oxidation and sulphate reduction rates were elevated at the pockmark site, reaching maximum values of 49 and $269 \mu \mathrm{mol} \mathrm{l}^{-1} \mathrm{~d}^{-1}$ respectively. The groundwater venting from the pockmark had an end member composition of $80 \mathrm{mM} \mathrm{Na}+1.0 \mathrm{mM} \mathrm{Ca}^{++}$and was depleted in $\mathrm{Mg}^{++}$. Due to mixing of these major cations along the groundwater/seawater interface, no $\mathrm{CaCO}_{3}$ precipitation was found around the pockmark site.
\end{abstract}

KEY WORDS: Methane oxidation rate $\cdot$ Sulphate reduction rate $\cdot$ Baltic Sea $\cdot$ Salinity $\cdot$ Sediments

\section{INTRODUCTION}

Submarine groundwater discharge and seawater cycling through marine sediments are important processes for the mass flux across sediment-water interfaces in marine environments. This mass flux, including nutrients and dissolved organic matter is important for biological productivity and geological mineralization processes (Simmons 1992). The movement of water across the sediment-water interface sets the microclimatic conditions for micro- and macrofauna inhabiting sediments (Riedl \& Machan 1972). Moreover, submarine groundwater discharge also may be a vehicle for biocides and other anthropogenic contaminants (Gallagher et al. 1996). Recent studies estimate the groundwater input into coastal waters to be about

Present addresses:

- University of Constance, Dep. Microbial Ecology, PO Box 5560, D-78457 Konstanz, Germany.

E-mail: ingeborg.bussman@uni-konstanz.de

- School of Ocean Sciences, University of Wales, Bangor, Menai Bridge, Anglesey LL59 5EY, United Kingdom
$40 \%$ of the river water flux, or about the order of a first order spring (Moore 1996). The amount of discharge may be estimated by using methane and radon as tracers (Cable et al. 1996).

Pockmark-like structures are a common feature at the northern and southern borders of Eckernförde Bay, western Baltic Sea (Werner 1978). These depressions are related to groundwater discharge from a landbased aquifer reaching into Eckernförde Bay (Liebau 1985). Irregular ground water discharge from the pockmark results in a reduction of salinity in the porewater of the surrounding sediments (Khandriche \& Werner 1994). The groundwater discharge dilutes bottom water salinities to values as low as $2.9 \mathrm{ppt}$, and methane concentrations in the bottom water range between 11 and $440 \mathrm{nmol} \mathrm{l^{-1 }}$, depending on the seepage activity (Bussmann \& Suess 1998).

The pockmarks in Eckernförde Bay are characterised by 2 aspects: (1) methane seeping out of the sediment and (2) the effect of low salinity groundwater intruding into marine sediments. Methane seeping out of the sediment is suspected to have a stimulating 
effect on microbial activities, as known for other seep environments (Dando et al. 1994a). The most important pathways of organic matter decomposition in Eckernförde Bay are sulphate reduction and methanogenesis (Pollehne 1986), indicated by a rapid depletion of sulphate and the high concentrations of methane in the sediments (Whiticar 1982). Stable $\mathrm{C}$ and $\mathrm{H}$ isotopic measurements of methane in the Bay indicate a relatively rapid methane oxidation in the upper $1 \mathrm{~m}$, while below $1 \mathrm{~m}$ the isotopic signal clearly points towards a strong methane production (Martens \& Albert 1994). In this study, we measured the sulphate reduction and methane oxidation rates as indicators of the methane consuming process in the upper sediment layers.

We also tried to assess the effect of the outflowing groundwater. Depending on the mixing ratio of freshto saltwater, the groundwater is suspected to have a detrimental effect on the fauna. The lowered salinity in the sediment will increase osmotic stress for the macrofauna. Calcium precipitation, a common feature of methane seeps, will also be influenced by the groundwater. Therefore the ion concentrations of the porewater, particularly those of calcium and magnesium, were also determined to better understand freshwater versus marine inputs.

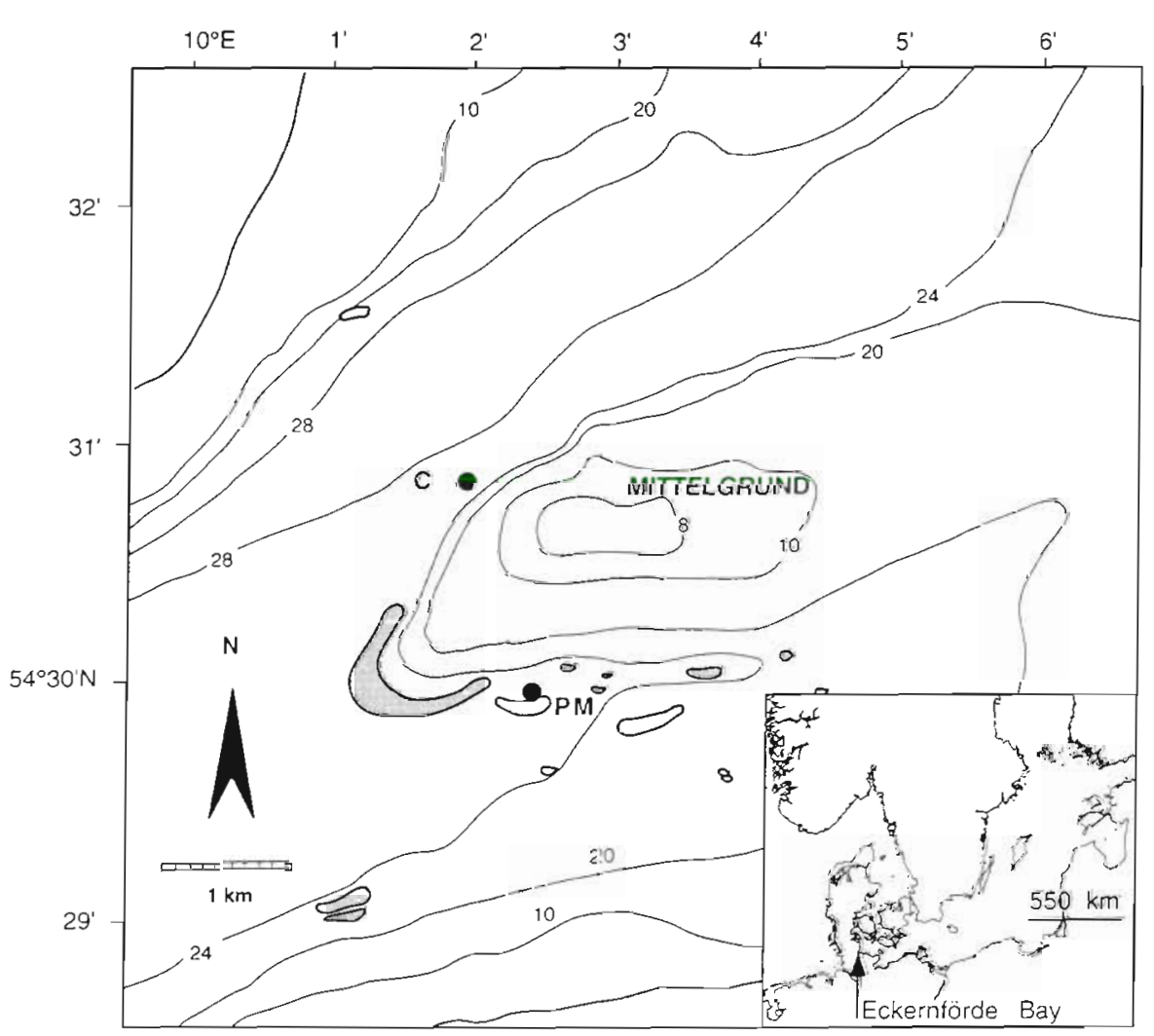

Fig. 1. Study area in Eckernförde Bay, western Baltic Sea. Shaded areas are pockmarks. PM: Pockmark site, C: control site

\section{MATERIAL AND METHODS}

Sediment sampling and porewater chemistry. Eckernförde Bay is a $17 \mathrm{~km}$ long and $3 \mathrm{~km}$ wide inlet of Kiel Bay situated in the western Baltic Sea (Fig. 1). Sediment samples were obtained with a small gravity corer (Rumohr-Lot, $1 \mathrm{~m}$ length, $10 \mathrm{~cm}$ diameter) at the pockmark site $\left(54^{\circ} 29.95^{\prime} \mathrm{N}, 10^{\circ} 2.28^{\prime} \mathrm{E}\right)$ and at a control site $\left(54^{\circ} 30.86^{\prime} \mathrm{N}, 10^{\circ} 1.88^{\prime} \mathrm{E}\right)$. Being at the same water depth of $25 \mathrm{~m}$, the control site north of Mittelgrund was in the same water body as the pockmark. Separate cores were taken at both sites for measurements of methane oxidation rate and sulphate reduction rate. All sediment cores were sampled initially at $2 \mathrm{~cm}$ intervals, followed by 5 and $10 \mathrm{~cm}$ intervals down to the maximal depth. Measurements of the porewater chemistry were done in December 1993, January 1994 and May 1994 to assess temporal variability. Measurements of the methane oxidation rate and sulphate reduction rate were only done in May 1994.

Methane concentration in the sediment (in $\mu \mathrm{mol} \mathrm{l^{-1 }}$ sediment) was obtained by the head-space method (Kiene \& Capone 1985). Porewater obtained by centrifugation was analyzed for chlorosity according to Grasshoff (1983) and for sulphate by ion chromatography (Petersen \& Ahring 1990). Dissolved sulphur species were determined by HPLC of their monobromobimane derivatives (Newton et al. 1981). Total sediment sulphides were reduced by chromous chloride to $\mathrm{H}_{2} \mathrm{~S}$, which was determined colorimetrically. Analytical methods for iron sulphides, elemental sulphur and sulphate followed those previously described (Dando et al. 1991). $\mathrm{Mg}^{++}$and $\mathrm{Ca}^{++}$in the interstitial water were determined by atomic absorption spectroscopy and $\mathrm{Na}^{+}$by atomic emission spectroscopy.

Methane oxidation rates. Measurements of the methane oxidation rate in the sediment of both sites were done in parallel subcores $(12 \mathrm{~cm}$ length, $2.4 \mathrm{~cm}$ diameter). Fifty $\mu$ l of an anoxic $\mathrm{NaCl}$ stock solution (15 ppt) containing $10 \mu \mathrm{M} \mathrm{CH}_{4}\left(2525 \mathrm{~Bq} \mathrm{ml} \mathrm{ml}^{-1}\right)$ were injected horizontally into the subcores. The cores were incubated near in situ temperature $\left(4^{\circ} \mathrm{C}\right)$ in the dark for $12 \mathrm{~h}$. The amounts of ${ }^{14} \mathrm{CH}_{4}$ and ${ }^{14} \mathrm{CO}_{2}$ formed were determined according to Iversen \& Jørgensen (1985). Due to low radioactivity of the $\mathrm{CO}_{2}$ fraction, counting was extended to $30 \mathrm{~min}$. Ad- 
ditionally, the amount of radioactivity fixed as assimilated carbon $\left({ }^{14} \mathrm{C}_{\text {assim }}\right)$ in the sediment was determined in triplicate by burning the dried sediment with an automatic Packard ${ }^{14} \mathrm{C}$ sample oxidizer for liquid scintillation counting. Preliminary control experiments had shown that shortly after the tracer addition $>95 \%$ of the radioactivity was recovered in the methane fraction. Rates of methane oxidation (in $\mu$ mol $\mathrm{l}^{-1}$ sediment $\mathrm{d}^{-1}$ ) were calculated from the amount of ${ }^{14} \mathrm{CO}_{2}$ and ${ }^{14} \mathrm{C}_{\text {assim }}$ in the sediment, from the methane concentration and the radioactivity of the added methane. Methane analysis was conducted with a Chrompack gas chromatograph (438 A) with a flame ionization detector, operating at $200^{\circ} \mathrm{C}$. Methane was separated on a Haysep $\mathrm{T}$ column (80/100 mesh, Chrompack). Temperature of the injector, the oven and the detector were 50,100 and $200^{\circ} \mathrm{C}$ respectively. Gas stream was $20 \mathrm{ml} \mathrm{min}{ }^{-1}$ with $\mathrm{N}_{2}$ as carrier gas, $25 \mathrm{ml} \mathrm{min}^{-1}$ with $\mathrm{H}_{2}$ and $250 \mathrm{ml} \mathrm{min}^{-1}$ with synthetic air.

Sulphate reduction rates. Sulphate reduction rate measurements were made in $4 \mathrm{ml}$ polystyrene syringe subcores which were injected along the length of the subcore with $5 \mu$ l of $\mathrm{K}_{2}{ }^{35} \mathrm{SO}_{4}$. The subcores were incubated in the dark for $6 \mathrm{~h}$ at $4^{\circ} \mathrm{C}$. Incubation was stopped by extruding the syringes into a zinc acetate solution (50 $\mathrm{g} \mathrm{l}^{-1}$ ) under a nitrogen atmosphere. After dispersing the sample by shaking, it was frozen until analysis. The reduced sulphur in the sediment was released by treating the sediment with acidified chromous chloride solution under argon, and trapping the hydrogen sulphide released in $5 \%$ zinc acetate solution (Zhabina \& Volkov 1978). The amount of radioactivity in the sulphide was determined by scintillation counting, after mixing the zinc acetate solution with scintillant (Packard Instagel), using the channel ratios method for quench correcting. The radioactivity of the ${ }^{35} \mathrm{SO}_{4}$ remaining was determined by counting aliquots of sediment washings. Interstitial water samples from parallel subcores were collected by centrifugation under an argon atmosphere, and sulphate was determined by HPLC after removing hydrogen sulphide in a stream of argon. The water content was measured by drying aliquots of the sediment to constant weight at $60^{\circ} \mathrm{C}$. Sulphate reduction rates were calculated by multiplying the proportion of the total ${ }^{35} \mathrm{~S}$ reduced by the fractionation factor and by the dissolved sulphate in $1 \mathrm{dm}^{3}$ sediment (Jørgensen 1978).

Oxidation of dissolved sulphide to sulphate during sample processing would lead to an apparently elevated sulphate reduction rate in sulphide-rich sediment such as those sampled in the pockmark. This does not apply to our cores since the samples from the horizons with most sulphide ( 30 to $40 \mathrm{~cm}$ ) showed no sulphate in the pockmark cores. Additionally incubation was performed in a sealed system to avoid any oxidation.
Macrofauna sampling. Samples through the bacterial mat in the pockmark were collected in $5 \mathrm{ml}$ cut-off syringes by SCUBA divers. These were examined by light microscopy. Box core samples $\left(0.25 \mathrm{~m}^{2}\right)$ were sieved through a $200 \mu \mathrm{m}$ mesh and the residue was preserved in $70 \%$ industrial alcohol before sorting under a stereomicroscope.

\section{RESULTS}

Temporal variations of porewater profiles at the pockmark and the control sites were investigated 3 times (6 December 1993, 25 January and 4 May 1994). Groundwater seepage was observed in December 1993 and May 1994, but not in January 1994.

Chloride concentrations at the control site showed no decrease with sediment depth in January or May (Fig. 2A). Chloride concentrations at the non-active pockmark (January 1994) slightly decreased with depth. However, with groundwater seepage (December and May), chlorosity rapidly decreased within the first $10 \mathrm{~cm}$; and subsequently stayed at about constant levels of an average of 106 and $36 \mathrm{mmol} \mathrm{l}^{-1}$ respectively (Fig. 2B).

Methane concentrations at the control site were an order of magnitude lower than at the pockmark at all times (Fig. 2C), but steadily increased with depth. In May methane concentrations exceeded the values of January. At the pockmark (Fig. 2D), methane concentrations in January and May showed a similar increase with depth, except the higher values at sediment depths below $30 \mathrm{~cm}$ for the January values. The seepage of groundwater in December straightened the methane profile, generating average levels of $257 \mu \mathrm{mol} \mathrm{l} \mathrm{l}^{-1}$ between 3 to $40 \mathrm{~cm}$ depth.

At the surface of the control site, sulphate concentrations ranged between 18 and $28 \mathrm{mmol} \mathrm{l}^{-1}$, decreasing to 5 to $6 \mathrm{mmol}^{-1}$ at the depth of $50 \mathrm{~cm}$ (Fig. 2E). At the pockmark site without groundwater seepage (January 1994) surface concentrations started with $20 \mathrm{mmol} \mathrm{l}^{-1}$. reaching zero values at a depth of $30 \mathrm{~cm}$ (Fig. 2F). On the dates with groundwater seepage, surface concentrations of sulphate rapidly decreased within the first $10 \mathrm{~cm}$. In December the sulphate was not depleted and showed an almost straight profile with an average of $3.77 \mathrm{mmol}^{-1}$. In May it reached zero values at a depth of $14 \mathrm{~cm}$.

Bacterial activities, i.e. methane oxidation and sulphate reduction rates, at the active pockmark site were higher compared with the control site for the May 1994 sampling date. At the control site methane concentrations increased steadily with sediment depth with a steep increase starting at $50 \mathrm{~cm}$ (Fig. 3A). The oxidation rate of methane revealed a similar pattern, remaining 
beneath $1 \mu \mathrm{mol} \mathrm{l^{-1 }} \mathrm{d}^{-1}$ until a depth of $40 \mathrm{~cm}$. Below $40 \mathrm{~cm}$ the activity increased reaching a maximum of

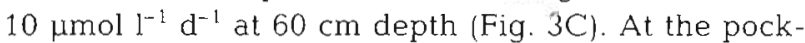

control

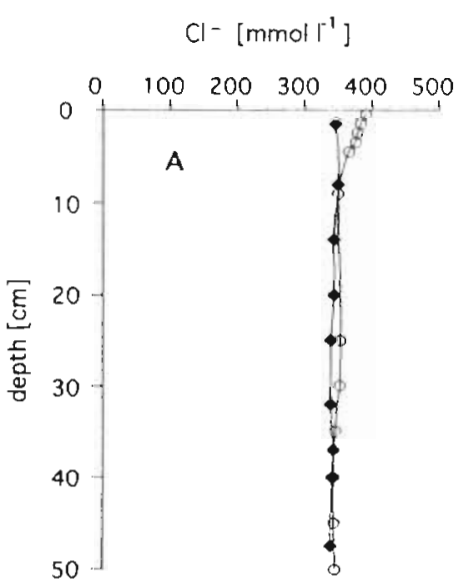

$\mathrm{C} \mathrm{H}_{4}\left[\mu \mathrm{mol} \mathrm{r}^{-1}\right]$

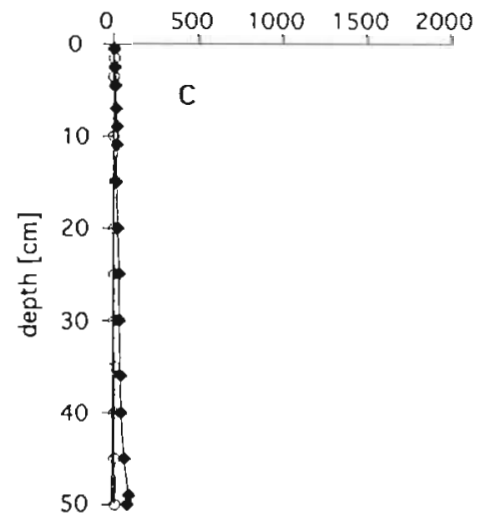

$\mathrm{S} \mathrm{O}_{4}^{-}\left[\mathrm{mmol} \mathrm{r^{-1 } ]}\right.$

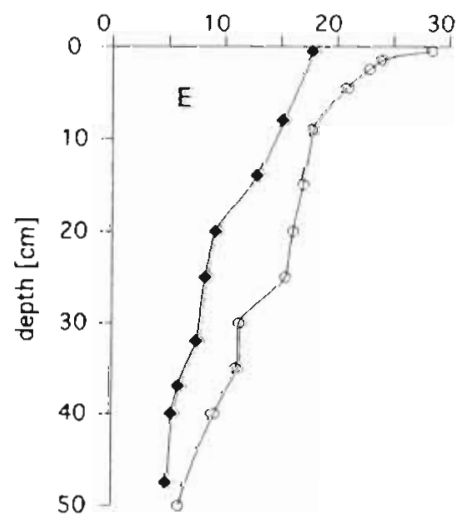

\section{pockmark}

$\mathrm{Cl}-\left[\mathrm{mmol}{ }^{-1}\right]$

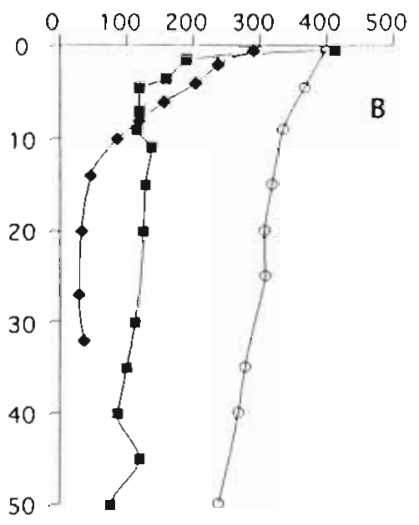

$\left.\mathrm{CH}_{4}[\mu \mathrm{mol} \mathrm{l})^{-1}\right]$

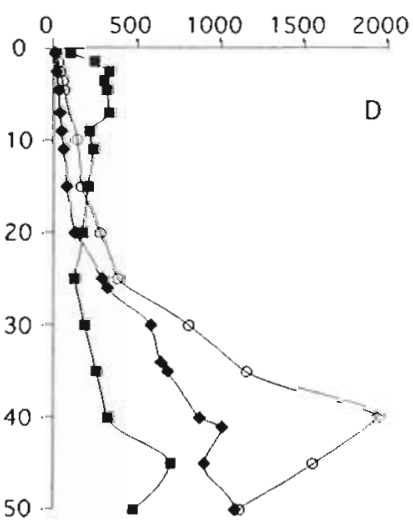

$\mathrm{SO}_{4}^{-}\left[\mathrm{mmol} \Gamma^{-1}\right]$

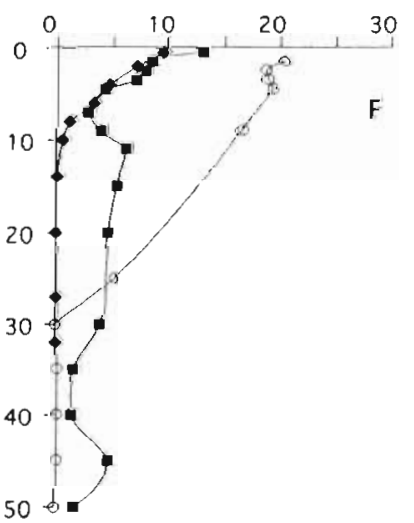

Fig. 2. Porewater concentrations of chloride, methane and sulphate at the control and pockmark sites. Sampling dates were: 6 December 1993, with seepage (ద); 25 January 1994, without seepage (0); 4 May 1994, with seepage ( $\bullet$ ). For the control site no data were available for December 1993 mark site, methane concentrations increased continuously until a depth of $20 \mathrm{~cm}$, and then increased rapidly to maximal values of $1372 \mu \mathrm{mol} \mathrm{l}^{-1}$ at a depth of $60 \mathrm{~cm}$

(Fig. 3B). Methane oxidation rate also steadily increased to a depth of $20 \mathrm{~cm}$ (Fig. 3D). Unlike in other cores with aerobic subsurface maxima (Frenzel et al. 1990), no such maximum was detected at the pockmark site, although oxygen penetrated to a depth of $13 \mathrm{~mm}$ (E. Sauter, GEOMAR, unpubl.). Below $20 \mathrm{~cm}$ the methane oxidation rate showed high variability and 3 maxima of activity, at $25 \mathrm{~cm}$ depth $\left(49 \mu \mathrm{mol} \mathrm{l} \mathrm{l}^{-1} \mathrm{~d}^{-1}\right)$.

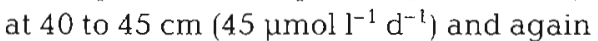

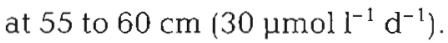

In May 1994, sulphate concentrations started with about the same concentrations at the surface, but in the seep core sulphate became more rapidly depleted (Fig. 4A,B). This effect is seen best after allowing for the diluting effect of the low ion-concentration discharge, and for water of varying salinity trapped in the sediment, by plotting the $\mathrm{SO}_{4}{ }^{2}: \mathrm{Mg}^{++}$ ratio (Fig. 5F). Both cores showed a similar immediate sub-surface maximum of sulphate reduction of 130 to $170 \mu \mathrm{mol} \mathrm{l^{-1 }}$ $\mathrm{d}^{-1}$ (Fig. 4A,B). In both cores this declined to approximately $20 \mu \mathrm{mol} \mathrm{l}^{-\mathrm{t}}$ sediment $\mathrm{d}^{-1}$ at $12 \mathrm{~cm}$ depth. The seep core showed, in addition, a larger second peak of activity just below $20 \mathrm{~cm}$ depth, a depth at which the sulphate concentration of only $0.5 \mathrm{mM}$ was probably limiting (Fig. 4B). This second peak of sulphate reduction, $269 \mu \mathrm{mol} \mathrm{l^{-1 }} \mathrm{d}^{-1}$ at $21 \mathrm{~cm}$ depth, in the seep core is responsible for the major sulphate consumption in the pockmark sediment and was nearly coincident with the maximum in methane oxidation activity at $25 \mathrm{~cm}$ depth (Fig. 3D).

To investigate the effects of the seepage on the macrofauna 1 box core from the pockmark was compared with a similar core from the control area. The only bivalves found were Corbula gibba and juvenile Mytilus edulis. The C. gibba had similar densities in both cores $270 \mathrm{~m}^{-2}$ in the seep core and $250 \mathrm{~m}^{-2}$ in the control core. $M$. edulis were absent in the seep core compared to $670 \mathrm{~m}^{-2}$ in the control. The presence of the young $M$. edulis in the control core was proba- 


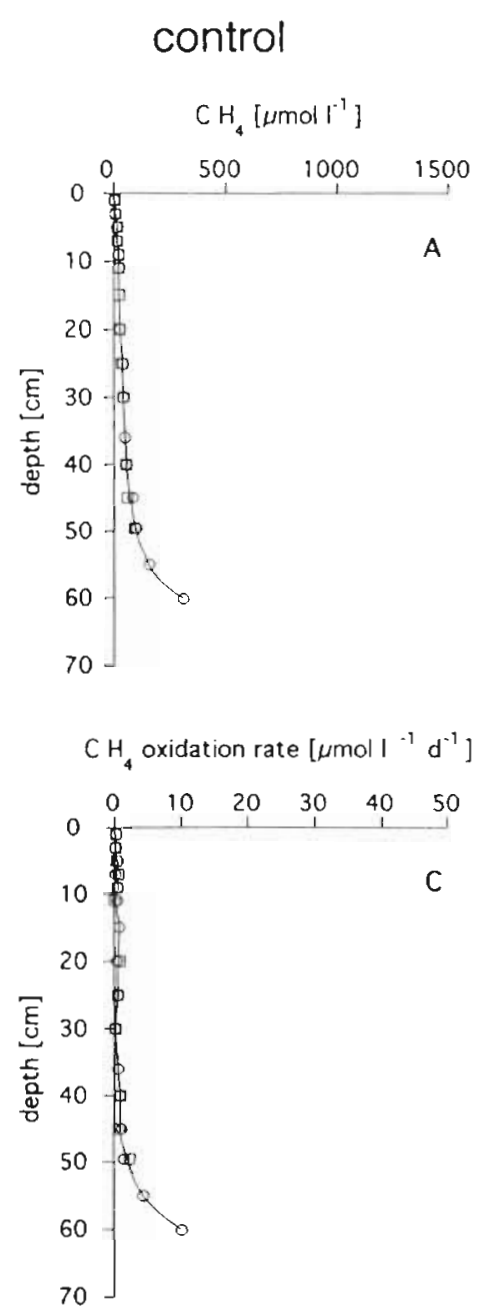

control

Fig. 3. Methane concentration and methane oxidation rate in 2 replicate subcores $(\square, 0)$ of control and pockmark sediments sampled on 4 May 1994. Note: this was a different core than shown in Fig. 2 pockmark

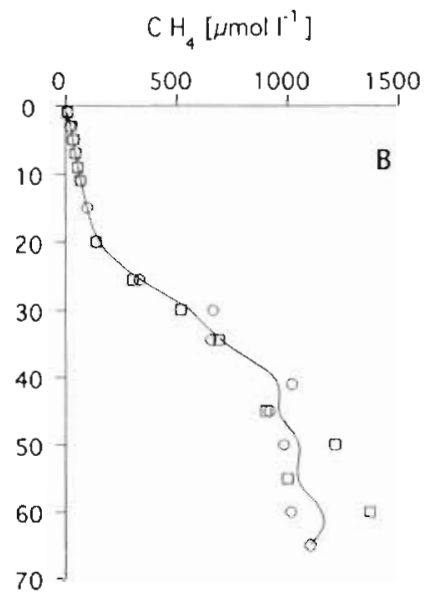

$\mathrm{CH}_{4}$ oxidation rate $\left[\mu \mathrm{mol} \mathrm{l}^{-1} \mathrm{~d}^{-1}\right.$ ]

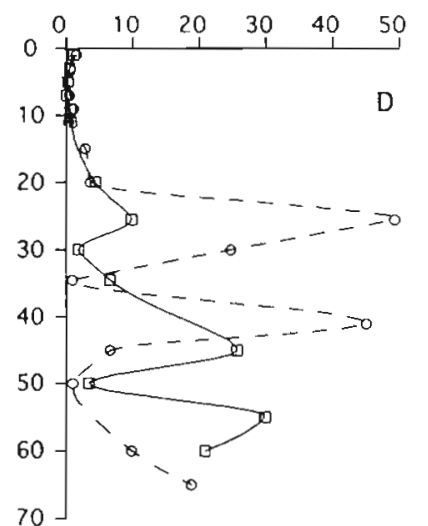

extrapolation to zero $\mathrm{Mg}^{++}$allowed estimates for the minimum concentrations in the underlying reservoir of $\mathrm{Na}^{+}$ (79.5 $\mathrm{mM}$ ) and $\mathrm{Ca}^{++}(1.0 \mathrm{mM})$.

Calcium concentrations rapidly decreased with depth in the pockmark core, due to dilution with groundwater containing lower ion concentrations (Fig. 5B). However the $\mathrm{Ca}^{++}: \mathrm{Mg}^{++}$ratio increased with depth in this core due to the presence of $\mathrm{Ca}^{++}$, but not $\mathrm{Mg}^{++}$, in discharging groundwater (Fig. 5D). The cation composition indicates that the outflowing vent water is enriched in dissolved $\mathrm{Ca}^{++}$and depleted in $\mathrm{Mg}^{++}$.

\section{DISCUSSION}

In the course of 6 mo the pockmark and control sites were sampled 3 times during periods with and without groundwater seepage. In May 1994 seepage activity was measured in situ with a benthic chamber, described by Linke et al. (1994). Flow rates varied, ranging from 170 to $472 \mathrm{l} \mathrm{m}^{-2} \mathrm{~d}^{-1}$ (P. Linke, GEOMAR, unpubl. data). Submarine groundwater fluxes along the eastern coast of the USA range between 5 and $10 \mathrm{l} \mathrm{m}^{-2} \mathrm{~d}^{-1}$ (Simmons 1992), whereas flow rates at the Aleutian subduction zone lie more within the range of our data, $240 \pm 2001 \mathrm{~m}^{-2} \mathrm{~d}^{-1}$ (Suess et al. 1998).

The most pronounced discharge was registered in December. This discharge

bly related to the presence of coarser sediment particles, allowing settlement of bivalve larvae. Annelids were dominated by spionid polychaetes, Polydora sp., with $760 \mathrm{~m}^{-2}$ in the seep core compared with $480 \mathrm{~m}^{-2}$ in the control.

In May 1994, the porewater chemistry of a pockmark core during a seepage situation showed a decline in ion concentrations $\left(\mathrm{Na}^{+}, \mathrm{Ca}^{++}, \mathrm{Mg}^{++}\right.$and $\left.\mathrm{SO}_{4}{ }^{=}\right)$with sediment depth (Figs. $4 \& 5$ ). In contrast, the control core showed much less variation with depth. Here, the pronounced peak in $\mathrm{Na}^{+}, \mathrm{Ca}^{++}, \mathrm{Mg}^{++}$and $\mathrm{SO}_{4}{ }^{\circ}$ at $12 \mathrm{~cm}$ depth, and the lesser peak at $16 \mathrm{~cm}$ depth are indicative of higher salinity water being trapped within the sediment. Plotting ratios of $\mathrm{Ca}^{++}$and $\mathrm{Na}^{+}$to $\mathrm{Mg}^{++}$ against depth (Fig. 5D,E) showed that the lower salinity water entering the base of the pockmark was very deficient in $\mathrm{Mg}^{++}$, relative to these other ions. Since the plots of $\mathrm{Mg}^{++}$against $\mathrm{Na}^{+}$and $\mathrm{Ca}^{++}$(Fig. 6) were linear, moved the concentration gradients of chloride and sulphate towards the sediment surface and straightened the methane profile. Without groundwater seepage the chloride profiles show a similar pattern to those at the control site.

The influence of the discharge in May on the porewater is more ambiguous than in December. The chloride profile clearly indicates a strong groundwater flow in May, which is even more pronounced than the one in December. This is in contrast with investigations from the water column, which indicate a weaker discharge in May than in December (Bussmann \& Suess 1998). Thus, for the methane profile, the May discharge conditions seemed to have less influence than conditions in December; it was more comparable to the non-discharge situation in January. But even under the non-discharge situation methane concentrations are much higher than at the control site in January. How- 


\section{control}
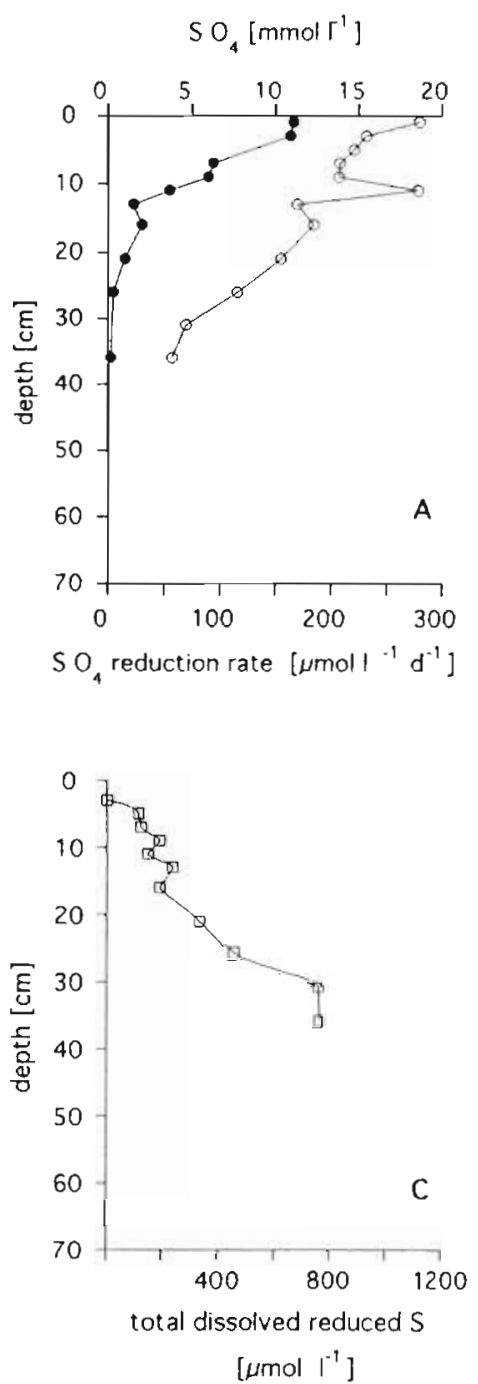

\section{pockmark}
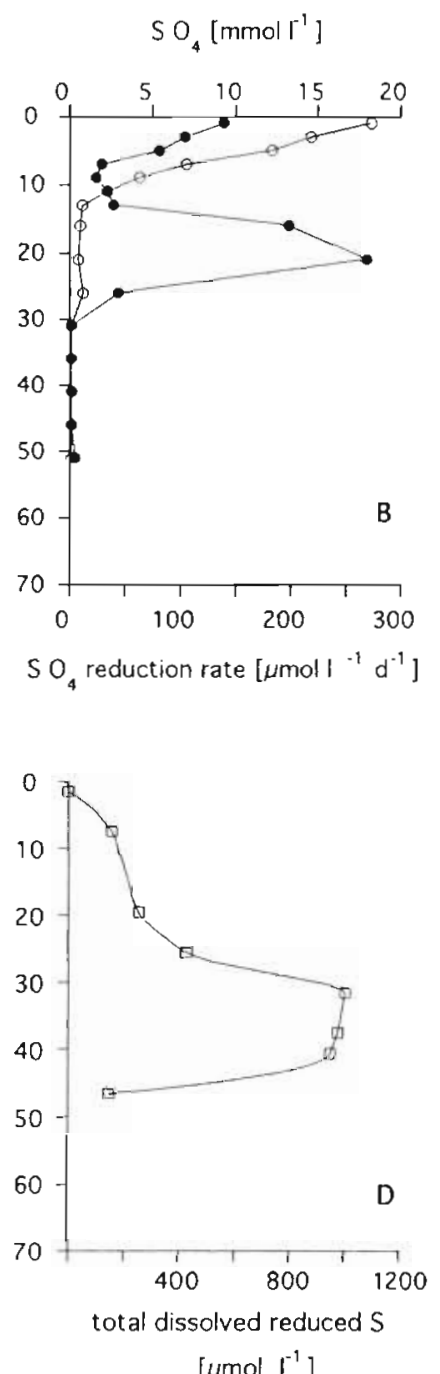

Fig. 4. Sulphate concentration (0), sulphate reduction rate $(\bullet)$ and total dissolved reduced sulphur species ( $\square$ ) in the sediments of the control and pockmark sampled on 4 May 1994

ever, higher methane concentrations at a pockmark site compared to a non-pockmark site are also reported from Martens \& Albert (1994). For sulphate in May there was no straightened profile like in December, but due to a strong sulphate reduction rate it was already depleted at $14 \mathrm{~cm}$ depth. This rapid depletion was probably due to the combined action of a strong sulphate reduction rate (Fig. 4) and seepage dilution (as seen from the corresponding chloride profile in Fig. 2)

The different reactions of the parameters on a seepage situation may be explained by a profound heterogeneity of the pockmark site. This heterogeneity may be spatial as well as temporal: SCUBA divers observed that the groundwater escapes the sediment in small fissures only a few centimeters wide (Khandriche \& Werner 1994).

At the methane seeps of Eckernförde Bay no calcium carbonate mineral precipitation takes place. The outflowing vent water may be described by its cation composition $180 \mathrm{mM}$ $\mathrm{Na}^{+}, 1 \mathrm{mM} \mathrm{Ca}^{++}$and no $\mathrm{Mg}^{++}$) as a low salinity water undersaturated with carbonate. The reason for the absence of carbonate precipitation is probably the higher solubility of the carbonate in the low salinity water, as well as the regular flushing of the pockmark sediments by the carbonate-undersaturated groundwater. This finding is opposite to most shallow water methane seeps, where the precipitation of calcium carbonate leads to cementation of the sediment (Jensen et al. 1992)

The absence of any cemented substrate may explain the nearly uniform distribution of macrofauna between the pockmark and the control site. Elevated biomass at cold-seeps is usually due to increased epifauna present on cemented sediment, e.g. the Kattegat methane seeps (Jensen et al. 1992), or to symbiotic associations, e.g. the Skagerrak methane seeps (Dando et al. 1994a). However in the pockmark investigated, there was no specialized macrofauna utilising either sulphide or methane, in contrast to the situation found in a North Sea pockmark (Dando et al. 1991). This may be due to the reduced salinity, since no symbiotic associations between animals and sulphur- or methane-oxidising bacteria have been recorded in freshwater or brackish conditions (Southward 1987).

The influence of the reduced salinity on bacterial activity at this methane seep was more complex. The comparison between the 2 sites reveals that the bacterial activity (methane oxidation and sulphate reduction) was elevated at the pockmark site (Table 1). Methane oxidation rates at the pockmark were at least 1 order of magnitude higher than at the control site, 1.13 to 4.06 versus $0.13 \mathrm{mmol} \mathrm{m} \mathrm{m}^{-2} \mathrm{~d}^{-1}$. The integrated sulphate reduction rates over the upper $35 \mathrm{~cm}$ of sediment showed a doubling of activity in the pockmark sediment, 33.1 versus $16.0 \mathrm{mmol} \mathrm{m} \mathrm{m}^{-2} \mathrm{~d}^{-1}$. This increase was due to the peak below $20 \mathrm{~cm}$ depth which corresponds to increasing methane concentrations and the first methane oxidation peak. This relation between stimulated sulphate reduction rates and elevated methane concentration is well known (e.g. Casper 1992).

The sulphate reduction rate maximum in the pockmark core was sufficient to deplete the available sul- 
phate in $4 \mathrm{~d}$. Since re-oxidation is unlikely at this sediment depth, there is probably lateral replenishment of seawater by its entrainment in the upward flux of low salinity water. This phenomenon is well known from entrainment observed in hydrothermal plumes at deep-sea vents (Humphris et al. 1995), as well as from methane seeps at shallow water depths (Dando et al. 1994b). Evidence for this comes from the sudden rise in magnesium, sodium and sulphate in the porewater above $30 \mathrm{~cm}$ depth (Figs. 5A,C \& 4B from the same core). The chloride and sulphate profiles of the May 1994 sample (Fig. 2) do not show such entrainments, as the measurements were not made in the same core. But entrainment as seen by elevated concentrations of chloride and sulphate did occur in the pockmark core of December 1993 (Fig. 2B,F) below $10 \mathrm{~cm}$ depth and again at $45 \mathrm{~cm}$ depth. Water flowing in from outside the active zone in the pockmark would be expected to be less depleted in chloride and sulphate.

The zone of elevated methane oxidation starts below $20 \mathrm{~cm}$ depth, coincident with elevated methane concentrations (Fig. 3). However, the methane oxidation rate seemed to be independent of the methane concentration. This disagrees with findings at methane seeps in the Skagerrak, where an increase of the methane oxidation rate was clearly related to an increase in methane concentration (Bussmann 1994). One explanation for the unusual behaviour of the methane oxidation rate in this study may be the decline in salinity. At the sediment surface, the salinity is still ca $10 \mathrm{ppt}$, but at a depth of $20 \mathrm{~cm}$ it is approaching $1 \mathrm{ppt}$, corresponding to a chlorosity of 165 and $20 \mathrm{mM}$, respectively (Fig. 2). Also the high variability of the methane oxidation rate (among the 2 parallel cores, as well as within each core) is remarkable. This variability is restricted to the region below $20 \mathrm{~cm}$. The methane concentrations and the methane oxidation rate in the upper sediment seemed to be reasonable, therefore the variability in the deeper layer is considered to be real and not an artifact. One explanation may be a very high spatial variability of some regulating factors, e.g. salinity. Another aspect may be related to how fast the bacter-
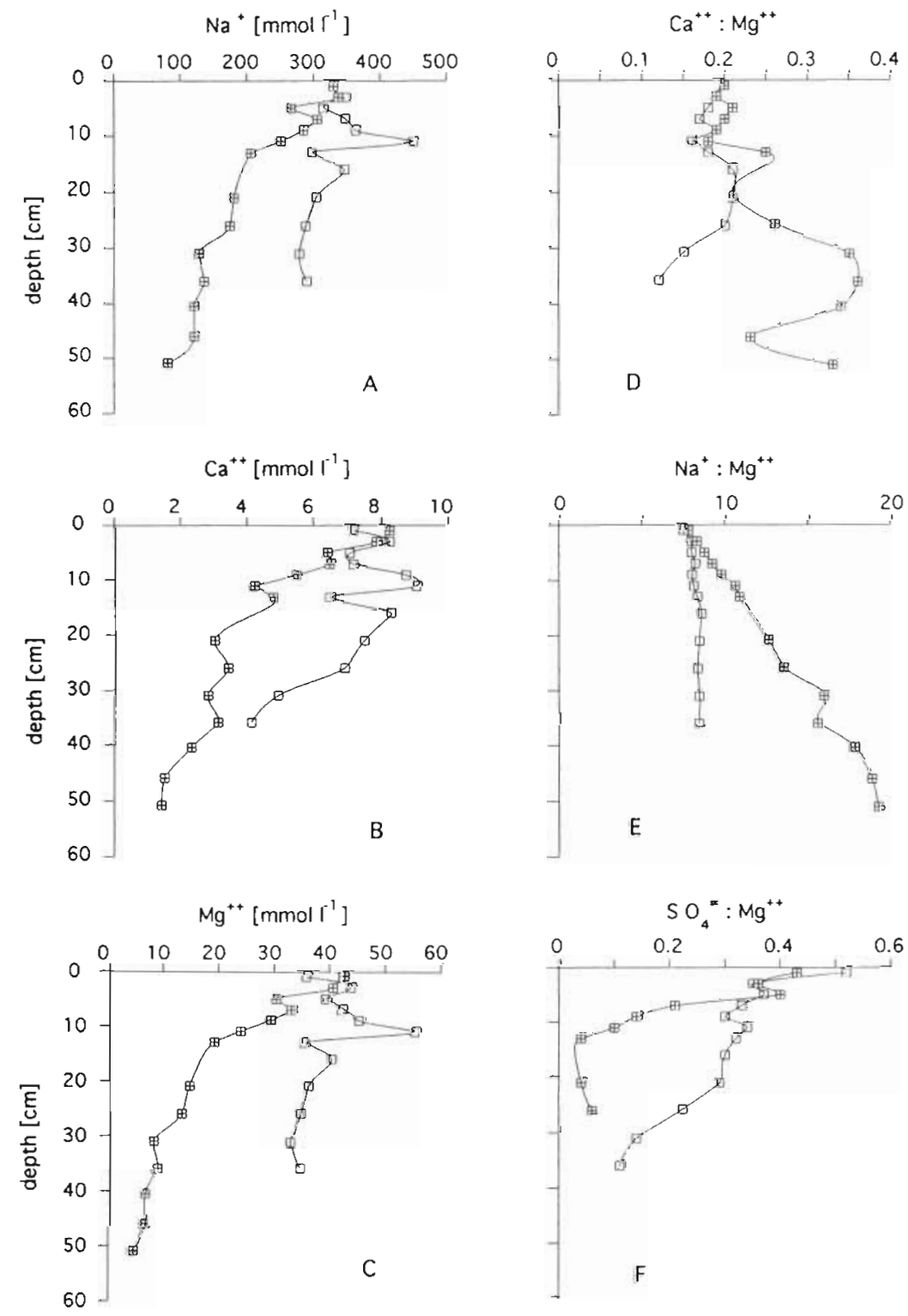

Fig. 5. Depth profiles in control (ㅁ) and pockmark ( $($ ) cores for (A) sodium, (B) calcium, (C) magnesium, (D) ratio of calcium to magnesium, (E) ratio of sodium to magnesium, (F) ratio of sulphate to magnesium. Note: this was the same core as in Fig. 4

Table 1. Integrated values of the methane oxidation rate (with 2 replicates $a$ and $b$ ) and the sulphate reduction rate over integrated sediment depths of 35 and $50 \mathrm{~cm}$

\begin{tabular}{|lccc|}
\cline { 2 - 4 } & $\begin{array}{c}\text { Integrated methane } \\
\text { oxidation rate } \\
(\text { mmol m }\end{array}$ & $\begin{array}{c}\text { Integrated sulphate } \\
\text { oxidation rate } \\
\left(\mathrm{mmol} \mathrm{m}^{-2} \mathrm{~d}^{-1}\right)\end{array}$ \\
\hline $35 \mathrm{~cm}$ & $50 \mathrm{~cm}$ & $35 \mathrm{~cm}^{-1}$ \\
\hline Pockmark a & 4.06 & 6.78 & 33.1 \\
Pockmark b & 1.13 & 3.52 & 16.0 \\
Control a & 0.13 & 0.28 & \\
Control b & 0.13 & 0.30 & \\
\hline
\end{tabular}



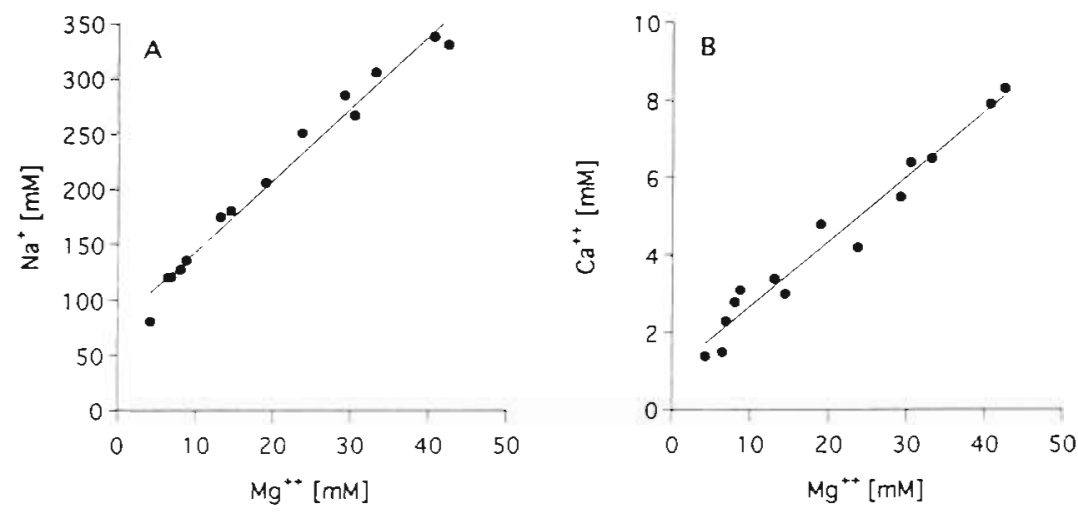

Fig. 6. Jon concentrations in interstitial water samples from the pockmark core: (A) ratio of sodium to magnesium, (B) ratio of calcium to magnesium known whether these unfavourable conditions may also be induced by salinity stress. Until recently little has been known about the bacteria mediating anaerobic methane oxidation; they have not been isolated or identified so far. Experiments with specific inhibitors have not brought much clarification (Alperin \& Reeburgh 1985). The most recent suggestion is a consortium of sulphate-reducing and methane-producing bacteria (Hoehler et al. 1994, Hansen et al. 1998). The way in which such a consortium would be influenced by changes in salinity remains speculative.

\section{CONCLUSION} reflected in strong variability More detailed investiga tions are necessary to clarify this aspect.

For bacteria of the water column it is known that in estuaries the mixing of freshwater with marine water causes bacterial counts and heterotrophic activity to decrease (Valdés \& Albright 1981). The process here is that marine bacteria are being exposed to groundwater. For the sulphate-reducing bacteria present, the impact of the groundwater discharge may be especially severe since the concentration of their electron acceptor is lowered by dilution. In this context, it is important to know the mixing rate of the discharging groundwater and the marine porewater. If it occurs over a short time span (hours), halophobic bacteria may die, while a slow mixing rate (days) would allow the development of halotolerant species without an overall decrease in bacterial abundance (Painchaud et al. 1995). Sediment bacteria of the seep are exposed to changes in salinity at regular intervals (Bussmann \& Suess 1998). Therefore, it can be assumed that a population of halotolerant sulphate reducers and methane oxidizers has been established. Another possibility is the coexistence of populations of halophile (marine) and non-halophile (limnic) bacteria alternating between active and dormant states. For sulphate reducers this would suggest 2 populations being adapted to high or low concentrations of their electron acceptor (Ingvorsen \& Jørgensen 1984, Bussmann \& Reichardt 1991).

Aerobic methane oxidizing bacteria are classified into 2 main groups (Type I and II), mainly based on $16 \mathrm{~S}$ rRNA sequencing (Brusseau et al. 1994). Some authors relate this assignment also to an ecological differentiation (Starostina et al. 1994). The activity of Type I is assumed to be the normally predominant $r$-strategist. Type II, as a $K$-strategist, is supposed to take over under unfavourable conditions. However, it is not
A comparison between a pockmark site with groundwater seepage and a control site revealed higher microbial activities of methane oxidation, sulphate reduction, as well as mats of sulphur oxidizing bacteria at the seep site. This elevated bacterial activity did not lead to higher densities of macrofauna or the presence of any symbiotic associations at the seep site. The pockmark site is an environment of high complexity. This complexity is revealed by the different responses of the investigated parameters to the groundwater discharge and by the change of porewater profiles at different sampling dates. Especially for methane and sulphate the porewater profiles at the seep site were influenced by groundwater seepage overlain by general seasonal variations.

Acknowledgements. This study was supported by the EU (MAS2-CT92-0040), the Deutsche Forschungsgesellschaft (SFB 313, Kiel) and by a NERC grant to P.R.D.

\section{LITERATURE CITED}

Alperin MJ, Reeburgh WS (1985) Inhibition experiments on anaerobic methane oxidation. Appl Environ Microbiol 50: $940-945$

Brusseau GA, Bulygina ES, Hanson RS (1994) Phylogenetic analysis and development of probes for differentiating methylotrophic bacteria. Appl Environ Microbiol 60:626-636

Bussmann I (1994) Verteilung und Steuergrößen der Aktivität Methan-oxidierender Bakterien in Randmeeren des Nordatlantiks. PhD thesis, University of Kiel

Bussmann I, Reichardt W (1991) Sulfate-reducing bacteria in temporarily oxic sediments with bivalves. Mar Ecol Prog Ser 78:97-102

Bussmann I, Suess E (1998) Ground-water seepage in Eckernförde Bay (western Baltic Sea): effect on methane and salinity distribution of the water column. Contin Shelf Res 18:1795-1806 
Cable JE, Bugna GC, Burnett WC, Chanton JP (1996) Application of ${ }^{222} \mathrm{Rn}$ and $\mathrm{CH}_{4}$ for assessment of grundwater discharge to the coastal ocean. Limnol Oceanogr 41. $1347-1353$

Casper P (1992) Methane production in lakes of different trophic state. Arch Hydrobiol 37:149-154

Dando PR, Austen MC, Burke RA, Kendall MA, Kennicutt MC, Judd AG, Moore DC, O'Hara SCM, Schmaljohann R, Southward AJ (1991) Ecology of a North Sea pockmark with an active methane seep. Mar Ecol Prog Ser 70: 49-63

Dando PR, Bussmann I, Niven S, O'Hara SCM, Schmaljohann $\mathrm{R}$, Taylor LJ (1994a) A methane seep area in the Skagerrak, the habitat of the pogonophore Siboglinum poseidoni, and the bivalve mollusc Thyasira sarsi. Mar Ecol Prog Ser $107: 157-167$

Dando PR, Jensen P, O'Hara SCM, Niven SJ, Schmaljohann R, Schuster U, Taylor LJ (1994b) The effects of methane seepage at an intertidal/shallow subtidal site on the shore of the Kattegat, Vendsyssel, Denmark. Bull Geol Soc Den $41(1): 65-79$

Frenzel P, Thebrath B, Conrad R (1990) Oxidation of methane in the oxic surface layer of a deep lake sediment (Lake Constance). FEMS Microbiol Ecol 73:149-158

Gallagher DL, Dietrich AM, Reay WG, Hayes MC, Simmons GM (1996) Ground water discharge of agricultural pesticides and nutrients to estuarine surface water Ground Water Monit Remediat 16:118-129

Grasshoff K (1983) Determination of salinity, Chap 3. In: Grasshoff K, Ehrhardt M. Kremling K (eds) Methods of seawater analysis. Verlag Chemie, Weinheim, p 38-45

Hansen LB, Finster K, Fossing H, Iversen N (1998) Anaerobic methane oxidation in sulfate depleted sediments: effects of sulfate and molybdate additions. Aquat Microb Ecol 14: 195-204

Hoehler TM, Alperin MJ, Albert DB, Martens CS (1994) Field and laboratory studies of methane oxidation in an anoxic marine sediment: evidence for a methanogen-sulfate reducer consortium. Global Biogeochem Cycles 8:451-463

Humphris SE, Herzig PM, Miller DJ, Alt JC, Becker K, Brown D, Bruegmann G, Chiba H, Fouquet YY (1995) The internal structure of an active sea-floor massive sulphide deposit. Nature 377:713-716

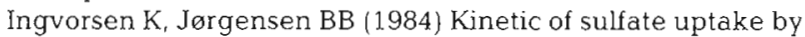
freshwater and marine species of Desulfovibrio. Arch Microbiol 139:61-66

Iversen $N$, Jørgensen BB (1985) Anaerobic methane oxidation rate at the sulfate-methane transition zone in marine sediments from Kattegat and Skagerrak (Denmark). Appl Environ Microbiol 30:944-955

Jensen P, Aagaard I, Burke RA, Dando PR, Jørgensen NO, Kukjpers A, Laier T, O Hara SCM, Schmaljohann R (1992) 'Bubbling reefs' in the Kattegat: submarine landscapes of carbonate-cemented rocks support a diverse ecosystem at methane seeps. Mar Ecol Prog Ser 83:103-112

Jørgensen BB (1978) A comparison of methods for the quantification of bacterial sulfate reduction in coastal marine sediments. I. Measurements with radiotracer techniques. Geomicrobiol J 1:11-64

Khandriche A, Werner F (1994) Freshwater induced pockmarks in Bay of Eckernförde, Western Baltic. In: Wever TF (ed) Proceedings of the Gassy Mud Workshop, Kiel. FWGReport 14, Forschungsanstalt der Bundeswehr für Wasserschall- und Geophysik, Kiel, p 24-30

Editorial responsibility: Gerhard Rheinheimer (Contributing Editor), Kiel, Germany
Kiene R, Capone DG (1985) Degassing of pore water methane during sediment incubations. Appl Environ Microbiol 49: $143-147$

Liebau C (1985) Hydrogeologische Untersuchungen eines tiefen Grundwasserleiters im Gebiet von Kiel. Nr 10. Reports from the Geol-Paleaontol Institute, University of Kiel

Linke P, Suess E, Torres M, Martens V, Rugh WD, Ziebis W, Kulm LD (1994) In situ measurement of fluid flow from cold seeps at active continental margins. Deep-Sea Res 41 $721-739$

Martens C, Albert D (1994) Biogeochemical processes controlling gas production, consumption and transport in organic-rich marine sediments. In: Wever TF (ed) Proceedings of the Gassy Mud Workshop, Kiel. FWG-Report. 14, Forschungsanstalt der Bundeswehr für Wasserschallund Geophysik, Kiel, p 101-107

Moore WS (1996) Large groundwater inputs to coastal water revealed by ${ }^{226} \mathrm{Ra}$ enrichments. Nature 380:612-617

Newton GL, Dorian R, Fahey RC (1981) Analysis of biological thiols: derivatization with monobromobimane and separation by reverse-phase high performance liquid chromatography. Anal Biochem 114:383-387

Painchaud J, Therriault JC, Legendre L (1995) Assessment of salinity-related mortality of freshwater bacteria in the Saint Lawrence estuary. Appl Environ Microbiol 61: 205-208

Petersen SP, Ahring BK (1990) Analysis of sulfate in sewage sludge using ion chromatographic techniques. J Microbiol Methods 12:225-230

Pollehne F (1986) Benthic nutrient regeneration processes in different sediment types of Kiel Bight. Ophelia 26:359-368

Riedl R, Machan R (1972) Hydrodynamic patterns in lotic intertidal sands and their bioclimatological implications. Mar Biol 13:179-209

Simmons GM (1992) Importance of submarine groundwater discharge (SGWD) and seawater cycling to material flux across sediment/water interfaces in marine environments. Mar Ecol Prog Ser 84:173-184

Southward EC (1987) Contribution of symbiotic chemoautotrophs to the nutrition of benthic invertebrates. In: Sleigh $M$ (ed) Microbes in the sea. Ellis Horwood Ltd, Chichester, p 83-118

Starostina NG, Pashkova NI, Gorkina NB, Tsiomenko AB (1994) Interactions among methanotrophs. Microbiology (NY) 63:308-312

Suess $E$, Bohrmann $G$, von Huene $R$, Linke P, Wallmann $K$, Lammers S, Sahlig $H$, Winckler G, Lutz RA, Orange D (1998) Fluid venting in the Aleutian subduction zone. J Geophys Res 103 (B2):2597-2614

Valdés M. Albright LJ (1981) Survival and heterotrophic activities of Fraser River and Strait of Georgia bacterioplankton within the Fraser River plume. Mai Biol 64: $231-241$

Werner F (1978) Depressions in mud sediments (Eckernförde Bay, Baltic Sea), related to sub-bottom and currents. Meyniana 30:99-104

Whiticar MJ (1982) The presence of methane bubbles in the acoustically turbid sediments of Eckernförde Bay, Baltic Sea. In: Manheim FT, Fanning KA (eds) Dynamic environment of the ocean floor. DC Heath, Lexington, MA, p 219-235

Zhabina NN, Volkov II (1978) A method of determination of various sulphur compounds in sea sediments and rocks. In: Krumbein WE (ed) Methods, metals and assessment. Science Publishers, Ann Arbor, p 735-746

Submitted: May 6, 1998; Accepted: October 19, 1998

Proofs received from author(s): February 22, 1999 